\title{
The Role of Specialized Lenders in Extending Mortgages to Lower-Income and Minority Homebuyers
}

Glenn B. Canner and Wayne Passmore, of the Board's Division of Research and Statistics, and Elizabeth Laderman, of the Federal Reserve Bank of San Francisco, prepared this article. Sylvia A. Freeland, Cynthia M. Johnson, and Melissa Mugharbel provided research assistance.

Home-purchase lending to lower-income and minority households and to residents of lower-income and minority neighborhoods has expanded significantly in recent years and at a faster rate than lending to other borrowers. Over the same period, however, an increasing proportion of applicants for conventional home-purchase mortgages (that is, mortgages not insured or guaranteed by the government), including lower-income and minority applicants, have had their applications denied. The first trend often has been taken as evidence that lenders' efforts to expand credit availability have been successful, whereas the second trend has contributed to concerns among some observers about access to credit and about the fairness of the lending process.

Among the commonly recognized factors promoting the overall growth of housing credit is the current prolonged economic expansion-which has resulted in strong employment growth and higher incomes-and lower interest rates and modest increases in home prices, which have improved the affordability of homes. The increase in the proportion of credit going to the lower-income and minority market has also been attributed to sharper competition for borrowers, to the introduction of new technologies that have lowered the costs of lending, and to the greater emphasis placed by banks and bank regulators on expanding the availability of such credit.

The conventional home-purchase mortgage market, which is much larger than the governmentbacked market, consists of three broad types of institution that specialize in mortgage lending-prime, subprime, and manufactured-home lenders. More than half of the growth in conventional homepurchase lending to lower-income and minority bor- rowers has come from prime lenders, institutions that generally focus on lending to the most creditworthy borrowers. But the overall share of the conventional home-purchase mortgage market attributable to prime lenders has actually fallen, from about 95 percent in 1993 to about 86 percent in 1998. This erosion in market share is attributable to an important but lessrecognized force behind the shift of credit toward lower-income and minority borrowers-the expansion of activity by lenders specializing in subprime and manufactured-home mortgages.

Subprime lenders concentrate on offering terms and seeking borrowers generally not acceptable to prime lenders, and the bulk of the customer base of manufactured-home lenders is households with lower levels of income and wealth. From 1993 to 1998, these specialized lenders more than tripled their share of the applications for conventional home-purchase loans (to about 34 percent), and they likewise nearly tripled their share of such loans extended (to about 14 percent).

Both subprime and manufactured-home lenders are oriented toward lower-income and minority households, among whom homeownership has spread more rapidly than among other households in recent years. ${ }^{1}$ These lenders have aggressively expanded their activity in the lower-income and minority market; moreover, since most of them are not subject to laws encouraging community investment, these lenders have expanded their activity without the goad of regulatory pressure applied by such laws. Because these lenders attract and vigorously market their services to less-creditworthy applicants, their emergence also bears directly on the sharp rise in mortgage

1. According to the Bureau of the Census's 1992 and 1998 Current Population Survey (CPS), the proportion of households that own their places of residence (homeownership rate) for households in the lowest income quartile increased 6.2 percent in the 1992-98 period, to 46.2 percent; in the highest income quartile, it increased 1.4 percent, to 85.9 percent.

In terms of racial and ethnic groups, the homeownership rate among whites in the $1992-98$ period increased 4.3 percent, to 72.6 percent; among blacks, it rose 8.2 percent, to 46.1 percent; and among Hispanics, it rose 12.0 percent, to 44.7 percent (CPS March Supplements). 
denial rates that has accompanied the rise in homepurchase lending.

In this article, we use data collected pursuant to the Home Mortgage Disclosure Act (HMDA) for the six years from 1993 to 1998 to measure the growing importance of institutions that specialize in subprime and manufactured-home lending. We find that part of the growth in mortgage lending and most of the increase in denial rates in the 1993-98 period are associated with the substantial and growing share of mortgages and mortgage applications processed by these institutions. ${ }^{2}$

\section{SUBPRIME AND MANUFACTURED-HOME LENDERS AND THE HMDA DATA}

Most mortgage lenders with offices in metropolitan areas are required by HMDA to provide annual data on the applications they receive for home mortgage credit and on the mortgage loans they originate and purchase (see appendix A for details). In 1998, mortgage lenders subject to HMDA accounted for an estimated three-fourths of all home-purchase loans extended nationwide; the coverage rate is likely higher in metropolitan areas, given the focus of the law.

The Congress enacted HMDA to help reveal the extent to which mortgage lenders are serving the housing credit needs of their local communities, including lower-income neighborhoods. Later revisions to HMDA increased the scope of the data reporting to help determine whether or not mortgage lenders are treating mortgage applicants fairly. HMDA data are used to evaluate the performance of commercial banks and savings associations under another federal law, the Community Reinvestment Act (CRA). ${ }^{3}$ In addition, the data are used to evaluate all types of mortgage lenders under fair lending laws, including the Equal Credit Opportunity Act and the Fair Housing Act.

Home-purchase mortgages may be broadly segmented into two types-conventional and government-backed-and data on both are collected under HMDA. We focus our discussion on the conventional market for several reasons. Conventional

2. For an earlier analysis of these patterns, see Randall M. Scheessele, The Impact of Manufactured Home and Subprime Loans on HMDA Rejection and Origination Rates, Housing Finance Working Paper Series (U.S. Department of Housing and Urban Development, November 1997).

3. For additional information on the CRA, see Griffith L. Garwood and Dolores S. Smith, "The Community Reinvestment Act: Evolution and Current Issues," Federal Reserve Bulletin, vol. 79 (April 1993), pp. 251-67.
1. Change in number of conventional home-purchase loans and change in rates of denial, by selected characteristics of applicant and census tract, 1993-98 Percent

\begin{tabular}{|c|c|c|}
\hline \multirow{2}{*}{ Characteristic } & \multicolumn{2}{|c|}{ Change } \\
\hline & Loans & Denial rate \\
\hline APPLICANT & & \\
\hline Income ratio & & \\
\hline Lower ..................... & 75.1 & 65.6 \\
\hline Middle & 52.8 & 59.5 \\
\hline Upper . & 52.4 & 8.7 \\
\hline Racial or ethnic identity & & \\
\hline American Indian or Alaskan Native & 52.5 & 90.3 \\
\hline Asian or Pacific Islander ........... & 50.6 & -19.2 \\
\hline Black ............... & 94.6 & 57.9 \\
\hline Hispanic & 77.7 & 54.2 \\
\hline White ... & 40.0 & 70.0 \\
\hline Census Tract & & \\
\hline Income $^{2}$ & & \\
\hline Lower & 77.8 & 48.6 \\
\hline Middle & 62.2 & 62.0 \\
\hline Upper . & 51.9 & 25.8 \\
\hline $\begin{array}{l}\text { Racial or ethnic composition } \\
\text { (minorities as percentage of population) }\end{array}$ & & \\
\hline Less than $10 \ldots \ldots \ldots \ldots \ldots \ldots \ldots$ & 47.9 & 61.0 \\
\hline $10-49 \ldots \ldots$ & 75.7 & 50.0 \\
\hline $50-100$ & 66.6 & 34.8 \\
\hline All $^{3}$ & 50.8 & 71.3 \\
\hline Мемо & & \\
\hline $\begin{array}{l}\text { Number of loans and overall } \\
\text { denial rate, } 1993 \ldots \ldots .\end{array}$ & $2,371,188$ & 17.2 \\
\hline
\end{tabular}

1. MSA median is median family income of the metropolitan statistical area (MSA) in which the property related to the loan is located.

2. Census tracts are categorized by the median family income for the tract relative to the median family income for the MSA in which the tract is located. Categories are defined as follows: lower income, median family income for census tract less than 80 percent of median family income for MSA; middle income, at least 80 percent and less than 120 percent of MSA median; upper income, at least 120 percent of MSA median.

3. Not all characteristics were reported for all applications; thus, the percentages in this line generally do not equal the weighted average of the percentages for specific characteristics.

SourCE. Here and in subsequent tables, Federal Financial Institutions Examination Council, Home Mortgage Disclosure Act data.

mortgages make up the bulk of home-purchase loans (about 80 percent of the home-purchase loans extended in 1998). Also, in the conventional market, private entities usually bear the credit risk, and thus their prices and underwriting standards for the most part reflect the costs of extending mortgage credit. In contrast, in the government-backed market, the public sector bears almost all of the risk, and the prices and underwriting standards are matters of government policy. ${ }^{4}$ In addition, most of the concerns expressed about the adequacy of lenders' efforts to serve lower-income and minority households and

4. The extent to which different institutions bear the credit risk of mortgages is examined in detail in Glenn B. Canner, Wayne Passmore, and Brian J. Surette, "Distribution of Credit Risk Among Providers of Mortgages to Lower-Income and Minority Homebuyers," Federal Reserve Bulletin, vol. 82 (December 1996), pp. 1077-1102. 
2. Home-purchase loans, grouped by type of lender and distributed by type of loan, 1998

\begin{tabular}{|c|c|c|c|c|c|c|c|c|c|c|c|c|}
\hline \multirow[b]{2}{*}{ Loan type } & \multicolumn{3}{|c|}{ Subprime } & \multicolumn{3}{|c|}{ Manufactured-home } & \multicolumn{3}{|c|}{ Prime } & \multicolumn{3}{|c|}{ All } \\
\hline & Number & Percent & \begin{tabular}{|c|} 
Mемо \\
Distribu- \\
tion of \\
loan type, \\
by lender
\end{tabular} & Number & Percent & $\begin{array}{c}\text { Mемо } \\
\text { Distribu- } \\
\text { tion of } \\
\text { loan type, } \\
\text { by lender }\end{array}$ & Number & Percent & $\begin{array}{c}\text { Memo } \\
\text { Distribu- } \\
\text { tion of } \\
\text { loan type, } \\
\text { by lender }\end{array}$ & Number & Percent & $\begin{array}{c}\text { MEмo } \\
\text { Distribu- } \\
\text { tion of } \\
\text { loan type, } \\
\text { by lender }\end{array}$ \\
\hline Government-backed & 14,986 & 6.4 & 1.5 & 745 & .3 & .1 & 957,534 & 23.8 & 98.4 & 973,265 & 21.4 & 100 \\
\hline FHA $\ldots \ldots \ldots \ldots$ & 12,913 & 5.5 & 1.8 & 653 & .2 & .1 & 719,020 & 17.8 & 98.1 & 732,586 & 16.1 & 100 \\
\hline Other $^{1}$ & 2,073 & .9 & .9 & 92 & $*$ & $*$ & 238,514 & 5.9 & 99.1 & 240,679 & 5.3 & 100 \\
\hline Conventional & 220,511 & 93.6 & 6.2 & 283,000 & 99.7 & 7.9 & $3,073,221$ & 76.2 & 85.9 & $3,576,732$ & 78.6 & 100 \\
\hline All & 235,497 & 100 & 5.2 & 283,745 & 100 & 6.2 & $4,030,755$ & 100 & 88.6 & $4,549,997$ & 100 & 100 \\
\hline
\end{tabular}

NoTE. Here and in subsequent tables, components may not sum to totals because of rounding.

1. Loans guaranteed by the Department of Veterans Affairs, the Farm Service Agency, and the Rural Housing Service.

* Less than 0.05 percent.

neighborhoods have historically centered on the conventional mortgage market.

From 1993 to 1998 the number of conventional home-purchase mortgages extended to lower-income borrowers increased about 75 percent, according to HMDA data, while lending to upper-income borrowers increased about 52 percent (table 1). Homepurchase lending to black and Hispanic borrowers in particular increased substantially over this period (95 percent and 78 percent respectively, compared with 40 percent for white borrowers). The pattern is similar across borrower groups in both the conventional market and the much smaller governmentbacked market (the latter of which consists mainly of mortgages insured by the Federal Housing Administration, or FHA - not shown in table).

Most of this growth can be attributed to the long economic expansion that began in 1991, low interest rates, and slow growth in home prices. ${ }^{5}$ In the conventional mortgage market, growth also has been promoted by the wider availability of new affordable loan products among prime lenders, such as mortgages with very low down payment requirements, and by the increasing activity of subprime and manufactured-home lenders.

Over the same period, the HMDA data show a rising denial rate for conventional home-purchase mortgages. From 1993 to 1998, the denial rate increased 71 percent, to a historically high level of 29 percent of all mortgage applicants. ${ }^{6}$ Denial rates for lower-income applicants rose nearly 66 percent, whereas denial rates for upper-income applicants rose

5. For an evaluation of the importance of different factors contributing to the growth in mortgage lending, see Douglas D. Evanoff and Lewis M. Segal, "CRA and Fair Lending Regulations: Resulting Trends in Mortgage Lending," Federal Reserve Bank of Chicago, Economic Perspectives (November/December 1996), pp. 19-46.

6. In contrast, denial rates for government-backed home-purchase mortgages fell nearly 40 percent over this period, to about 8 percent (not shown in tables). only 9 percent. Among racial and ethnic groups, denial rates increased substantially for all groups except Asian applicants, for whom denial rates fell. As discussed below, manufactured-home lenders have played the major role in these changes, with subprime lenders also having an important influence.

\section{MANUFACTURED HOMES AND THE HOUSING MARKET}

Manufactured housing is a growing, although sometimes overlooked, segment of the housing market and provides homeownership opportunities for many households, particularly those with lower levels of income and wealth. In contrast with homes built at the purchaser's site ("site-built" homes), manufactured homes are assembled in a factory, transported to the purchaser's site, and typically placed on a permanent foundation. Once placed on the foundation, the home may receive some enhancements, such as the addition of a porch or deck.

About 8 percent of the U.S. population resides year-round in roughly 9 million manufactured homes. $^{7}$ In 1998, about 80 percent of the residents of manufactured homes owned their homes. ${ }^{8}$ In contrast, the ownership rate for other nonfarm, one- to four-family houses was about 64 percent.

Annual shipments of new manufactured homes grew about 47 percent, to 373,000 homes, from 1993 to 1998. Over the same period, the annual number of new site-built homes increased 24 percent, to 1.47 million homes. Currently, nearly 20 percent of

7. Manufactured homes are sometimes referred to as "mobile homes" but are rarely moved after initial placement on a site. This housing category does not include recreational vehicles. For more information, see Manufactured Housing Institute, Just the Facts (Arlington, Va., March 25, 1999).

8. Board of Governors of the Federal Reserve System, 1998 Survey of Consumer Finances. 
3. Borrowers of conventional home-purchase loans, grouped by type of lender and distributed by selected characteristics of borrower and census tract, 1998

Percent

\begin{tabular}{|c|c|c|c|c|c|c|c|c|c|c|c|c|}
\hline \multirow[b]{2}{*}{ Characteristic } & \multicolumn{3}{|c|}{ Subprime } & \multicolumn{3}{|c|}{ Manufactured-home } & \multicolumn{3}{|c|}{ Prime } & \multicolumn{3}{|c|}{ All } \\
\hline & Number & Percent & $\begin{array}{c}\text { MEмo } \\
\text { Percentage } \\
\text { of loans to } \\
\text { borrower } \\
\text { group, by } \\
\text { lender type }\end{array}$ & Number & Percent & $\begin{array}{c}\text { Мемо } \\
\text { Percentage } \\
\text { of loans to } \\
\text { borrower } \\
\text { group, by } \\
\text { lender type }\end{array}$ & Number & Percent & $\begin{array}{c}\text { МЕмо } \\
\text { Percentage } \\
\text { of loans to } \\
\text { borrower } \\
\text { group, by } \\
\text { lender type }\end{array}$ & Number & Percent & $\begin{array}{c}\text { Мемо } \\
\text { Percentage } \\
\text { of loans to } \\
\text { borrower } \\
\text { group, by } \\
\text { lender type }\end{array}$ \\
\hline \multicolumn{13}{|l|}{$\begin{array}{l}\text { BORROWER } \\
\text { Income ratio (percentage } \\
\text { of MSA median) }\end{array}$} \\
\hline Lower...$\ldots \ldots \ldots \ldots$ & 48,711 & 28.5 & 6.8 & 97,845 & 58.4 & 13.7 & 566,134 & 22.0 & 79.4 & 712,690 & 24.4 & 100 \\
\hline Middle ........ & 47,274 & 27.7 & 6.3 & 44,171 & 26.4 & 5.9 & 662,614 & 25.7 & 87.9 & 754,059 & 25.9 & 100 \\
\hline Upper . & 74,676 & 43.8 & 5.1 & 25,475 & 15.2 & 1.8 & $1,349,93$ & 52.3 & 93.1 & $1,450,08$ & 49.7 & 100 \\
\hline All & 170,661 & 100 & 5.9 & 167,491 & 100 & 5.7 & $2,578,682$ & 100 & 88.4 & $2,916,834$ & 100 & 100 \\
\hline \multicolumn{13}{|l|}{ Racial or ethnic identity } \\
\hline Alaskan Native & 1,076 & 6 & 8.2 & 2,773 & 1.1 & 21.0 & 9,326 & .3 & 70.8 & 13,175 & .4 & 100 \\
\hline Asian or Pacific Islander & 7,987 & 4.5 & 6.7 & 1,283 & .5 & 1.1 & 109,216 & 3.9 & 92.2 & 118,486 & 3.7 & 100 \\
\hline Black $\ldots \ldots \ldots \ldots \ldots$ & 24,689 & 13.9 & 15.6 & 27,750 & 10.5 & 17.5 & 105,827 & 3.8 & 66.9 & 158,266 & 4.9 & 100 \\
\hline Hispanic .... & 16,893 & 9.5 & 10.4 & 16,931 & 6.4 & 10.4 & 128,541 & 4.6 & 79.2 & 162,365 & 5.1 & 100 \\
\hline White ........ & 127,523 & 71.6 & 4.6 & 215,230 & 81.5 & 7.8 & $2,417,617$ & 87.3 & 87.6 & $2,760,370$ & 85.9 & 100 \\
\hline All & 178,168 & 100 & 5.5 & 263,967 & 100 & 8.2 & $2,770,527$ & 100 & 86.2 & $3,212,662$ & 100 & 100 \\
\hline \multicolumn{13}{|l|}{ Census Tract } \\
\hline Lower ... & 38,808 & 20.3 & 12.0 & 37,121 & 22.9 & 11.5 & 247,866 & 9.5 & 76.6 & 323,795 & 10.9 & 100 \\
\hline Middle & 90,743 & 47.5 & 6.4 & 102,609 & 63.2 & 7.2 & $1,223,007$ & 46.8 & 86.3 & $1,416,359$ & 47.7 & 100 \\
\hline Upper ... & 61,608 & 32.2 & 5.0 & 22,644 & 13.9 & 1.8 & $1,143,066$ & 43.7 & 93.1 & $1,227,318$ & 41.4 & 100 \\
\hline All & 191,159 & 100 & 6.4 & 162,374 & 100 & 5.5 & $2,613,939$ & 100 & 88.1 & $2,967,472$ & 100 & 100 \\
\hline $\begin{array}{l}\text { Racial or ethnic } \\
\text { composition (minorities } \\
\text { as a percentage } \\
\text { of population) }\end{array}$ & & & & & & & & & & & & \\
\hline Less than $10 \ldots$ & 69,648 & 36.5 & 4.4 & 73,095 & 45.0 & 4.6 & $1,451,780$ & 55.7 & 91.0 & $1,594,523$ & 53.8 & 100 \\
\hline $10-49 \ldots \ldots$ & 88,670 & 46.5 & 7.7 & 71,620 & 44.1 & 6.2 & 997,974 & 38.3 & 86.2 & $1,158,264$ & 39.1 & 100 \\
\hline $50-100 \ldots$ & 32,437 & 17.0 & 15.6 & 17,756 & 10.9 & 8.5 & 158,259 & 6.1 & 75.9 & 208,452 & 7.0 & 100 \\
\hline All & 190,755 & 100 & 6.4 & 162,471 & 100 & 5.5 & $2,608,013$ & 100 & 88.1 & $2,961,239$ & 100 & 100 \\
\hline
\end{tabular}

NoTE. Not all characteristics were reported for all applications; thus, the total number of applications with racial or ethnic group identified varies from the total with income identified. See also notes to table 1 .

new single-family residences are manufactured homes. ${ }^{9}$

Homebuyer interest in manufactured homes stems in part from their relatively low price per square foot-on average about 50 percent lower than that of site-built homes. ${ }^{10}$ The lower price per square foot for manufactured homes reflects, in part, economies of scale in production that result from their being

9. U.S. Department of Housing and Urban Development, U.S. Housing Market Conditions, table 5-"Manufactured (Mobile) Home Shipments, Residential Placements, Average Prices, and Units for Sale: 1974-Present"; and table 6-"New Privately Owned Housing Units Completed: 1968-Present." The data are through the first quarter of 1999.

10. In 1997, a new manufactured home on average had 1,420 square feet of living area and cost $\$ 41,100$ ( $\$ 29$ per square foot), while the average new site-built home had 2,150 square feet and cost (excluding its site) $\$ 132,150$ ( $\$ 61$ per square foot). See Manufactured Housing Institute, Average Sales Price of New Manufactured Homes Placed for Residential Use: All Homes, Single Section and Multisection Homes (1990-1997) (Arlington, Va., 1998). constructed in factories and shipped largely complete to a dealer or homeowner.

An increased variety of styles and amenities has also raised homebuyer interest in manufactured homes in recent years. One type of product-the multisectional home- has grown in popularity and now accounts for nearly three-fifths of manufacturedhome production. In addition, the use of better construction techniques and materials has extended the useful lives of newer manufactured homes-the industry estimates that the "habitable life" for such homes built over the past two decades exceeds seventy years. ${ }^{11}$ In turn, as the lifespan of manufactured homes has lengthened, lenders have become more willing to finance purchases over longer periods. Most loans for new units are still for fifteen years or

11. Carol B. Meeks, Manufactured Home Life: Existing Housing Stock through 1997 (Manufactured Housing Institute, Arlington, Va., May 1998). 
less, but the maturities on more than 40 percent of the loans on new multisection units exceed fifteen years, and some lenders offer loans with maturities of thirty years. ${ }^{12}$

Because of their relatively low cost, manufactured homes are an important housing option for households of modest means, including first-time homebuyers. In 1995 the median household income of manufactured-home owners was $\$ 22,000$, and their median net worth was nearly $\$ 27,000$. By comparison, the median household income for all other homeowners that year was about $\$ 42,000$, and their median net worth was $\$ 117,000 .{ }^{13}$

\section{IDENTIFYING SPECIALIZED LENDERS IN THE HMDA DATA}

The identity of specialized lenders cannot be determined directly from the HMDA data, which do not generally include information on the credit quality of applications and loans (relevant for identifying subprime lenders) nor on the type of homes involved (relevant for identifying manufactured-home lenders). ${ }^{14}$ But by combining information from HMDA and other sources, specialized lenders who reported HMDA data over the 1993-98 period can be identified (for details, see appendix B).

\section{Manufactured-Home Lending}

Relatively few of the institutions covered by HMDA specialize in manufactured-home lending, although many institutions, including many community banks, offer such loans. The twenty-two manufactured-home loan specialists identified in the 1998 HMDA data (table B.1) received 1.6 million applications for conventional home-purchase loans (not shown in table), and they extended 283,000 such loans. The U.S. Department of Housing and Urban Development (HUD) has estimated that these loans accounted for about half of all loans extended in 1998 for new and used manufactured homes and also that, of loans

12. Manufactured Housing Institute, Manufactured Home Financing (Arlington, Va., 1998).

13. For a general description of the survey from which these figures were derived, see Arthur B. Kennickell, Martha Starr-McCluer, and Annika E. Sunden, "Family Finances in the U.S.: Recent Evidence from the Survey of Consumer Finances," Federal Reserve Bulletin, vol. 83 (January 1997), pp. 1-24.

14. The Federal Reserve Board is reviewing its Regulation C, which implements HMDA. Among the changes under consideration is a requirement for lenders to identify whether an application or loan involves a manufactured home.
4. Share of change in number of conventional homepurchase loans, grouped by selected characteristics of borrower and census tract and distributed by type of lender, 1993-98

Percent

\begin{tabular}{|c|c|c|c|c|}
\hline Characteristic & Subprime & $\begin{array}{l}\text { Manu- } \\
\text { factured- } \\
\text { home }\end{array}$ & Prime & All \\
\hline \\
\hline $\begin{array}{l}\text { Income ratio } \\
\text { (percentage of } \\
\text { MSA median) }\end{array}$ & & & & \\
\hline & 15.1 & 25.3 & 59.6 & 100 \\
\hline Middle & 16.9 & 13.5 & 69.6 & 100 \\
\hline Upper . & 13.9 & 4.1 & 82.0 & 100 \\
\hline \multicolumn{5}{|c|}{ Racial or ethnic identity } \\
\hline $\begin{array}{l}\text { American Indian or } \\
\text { Alaskan Native }\end{array}$ & 22.6 & 48.3 & 29.1 & $10 c$ \\
\hline Asian or Pacific & & & & \\
\hline Islander & 17.2 & 2.4 & 80.5 & 100 \\
\hline Black ........ & 30.5 & 26.9 & 42.6 & 100 \\
\hline Hispanic & 22.3 & 18.7 & 59.0 & 100 \\
\hline White ....... & 15.0 & 16.0 & 69.0 & 100 \\
\hline \multicolumn{5}{|l|}{ Census Tract } \\
\hline Lower ..... & 26.1 & 21.9 & 52.1 & 100 \\
\hline Middle & 15.9 & 14.6 & 69.6 & 100 \\
\hline Upper . & 13.6 & 4.3 & 82.1 & 100 \\
\hline All . & 17.0 & 14.9 & 68.1 & 100 \\
\hline \multicolumn{5}{|l|}{$\begin{array}{l}\text { Racial Composition } \\
\text { (minorities as a } \\
\text { percentage of } \\
\text { population) }\end{array}$} \\
\hline Less than $10 .$. & 13.0 & 10.7 & 76.3 & 100 \\
\hline $10-49 \ldots \ldots$ & 16.4 & 11.6 & 71.9 & 100 \\
\hline $50-100$ & 36.4 & 18.1 & 45.5 & 100 \\
\hline All & 17.0 & 14.9 & 68.1 & 100 \\
\hline
\end{tabular}

Note. See notes to table 1 .

extended for new units, the specialists likely accounted for well more than half. ${ }^{15}$

More than 99 percent of the loans extended for the purchase of manufactured homes are conventional, although some government agencies, including the FHA and the Department of Veterans Affairs, insure or guarantee loans to purchase manufactured homes (table 2). In 1998, manufactured-home lenders received 24 percent of the 6.7 million applications for conventional home-purchase loans reported under HMDA (not shown in table) and accounted for 8 percent of all the conventional home-purchase mortgages.

Mortgages on manufactured homes generally have several characteristics that produce a degree of credit risk higher than that for loans collateralized by sitebuilt homes. First, lenders for manufactured homes tend to require lower down payments because buyers of these homes generally have lower levels of income

15. See Randall M. Scheessele, 1998 HMDA Highlights, Housing Finance Working Papers (U.S. Department of Housing and Urban Development, October 1999), appendix D. 
5. Share of conventional home-purchase loans, grouped by selected characteristics of borrower and census tract and distributed by type of lender, 1993 and 1998

Percent

\begin{tabular}{|c|c|c|c|c|c|c|c|c|}
\hline \multirow{2}{*}{ Characteristic } & \multicolumn{4}{|c|}{1993} & \multicolumn{4}{|c|}{1998} \\
\hline & Subprime & $\begin{array}{l}\text { Manufactured- } \\
\text { home }\end{array}$ & Prime & All & Subprime & $\begin{array}{c}\text { Manufactured- } \\
\text { home }\end{array}$ & Prime & All \\
\hline $\begin{array}{l}\quad \text { BORROWER } \\
\text { Income ratio } \\
\text { (percentage of MSA median) }\end{array}$ & & & & & & & & \\
\hline Lower …................... & .6 & 5.0 & 94.3 & 100 & 6.8 & 13.7 & 79.4 & 100 \\
\hline Middle & .6 & 1.8 & 97.5 & 100 & 6.3 & 5.9 & 87.9 & 100 \\
\hline Upper ....... & .6 & .5 & 98.9 & 100 & 5.1 & 1.8 & 93.1 & 100 \\
\hline $\begin{array}{l}\text { Racial or ethnic identity } \\
\text { American Indian or }\end{array}$ & & & & & & & & \\
\hline Alaskan Native & .6 & 6.7 & 92.7 & 100 & 8.2 & 21.0 & 70.8 & 100 \\
\hline Asian or Pacific Islander & 1.5 & .4 & 98.1 & 100 & 6.7 & 1.1 & 92.2 & 100 \\
\hline Black ................ & 1.5 & 8.7 & 89.8 & 100 & 15.6 & 17.5 & 66.9 & 100 \\
\hline Hispanic & 1.2 & 4.0 & 94.8 & 100 & 10.4 & 10.4 & 79.2 & 100 \\
\hline White ... & .5 & 4.5 & 95.0 & 100 & 4.6 & 7.8 & 87.6 & 100 \\
\hline 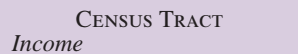 & & & & & & & & \\
\hline Lower & 1.0 & 3.4 & 95.6 & 100 & 12.0 & 11.5 & 76.6 & 100 \\
\hline Middle & .5 & 2.7 & 96.8 & 100 & 6.4 & 7.2 & 86.3 & 100 \\
\hline ........... & .6 & .6 & 98.9 & 100 & 5.0 & 1.8 & 93.1 & 100 \\
\hline $\begin{array}{l}\text { Racial Composition } \\
\text { (minorities as a percentage } \\
\text { of population) }\end{array}$ & & & & & & & & \\
\hline Less than $10 \ldots \ldots$ & .2 & 1.6 & 98.1 & 100 & 4.4 & 4.6 & 91.0 & 100 \\
\hline $10-49$ & 1.0 & 2.1 & 96.9 & 100 & 7.7 & 6.2 & 86.2 & 100 \\
\hline $50-100$ & 1.6 & 2.1 & 96.3 & 100 & 15.6 & 8.5 & 75.9 & 100 \\
\hline All & .7 & 4.4 & 95.0 & 100 & 6.2 & 7.9 & 85.9 & 100 \\
\hline
\end{tabular}

Note. See notes to table 1.

and wealth than buyers of site-built homes. ${ }^{16}$ Second, manufactured-home borrowers have fewer resources on which to rely during financial difficulties, again because they generally have lower incomes and less wealth. This lack of a financial cushion is reflected in a relatively high delinquency rate for these loans. ${ }^{17}$ Third, the applicants for manufactured-home loans tend on average to have weaker credit histories than mortgage applicants in the prime market. Given the higher risks associated with the borrowers in this market, lenders tend to deny a higher proportion of applications and to charge higher interest rates for the mortgages.

A factor that may exaggerate the denial rate for manufactured-home loans is the practice among dealers of manufactured homes to "shop" the credit

\footnotetext{
16. In 1997, about three-fifths of the loans for purchasing new manufactured homes were extended with down payments of 15 percent or less. In contrast, more than three-fifths of homebuyers of newly constructed site-built homes made a down payment of 20 percent or more (Manufactured Housing Institute, Manufactured Home Financing, p. 6).

17. For example, on average in 1998, 4.7 percent of manufacturedhome mortgages held by commercial banks were delinquent, compared with 3.0 percent for conventional site-built home mortgages held by all mortgage lenders. See American Bankers Association, Consumer Credit Delinquency Bulletin (Washington, D.C., fourth quarter 1998); and Mortgage Bankers Association of America, National Delinquency Survey (Washington, D.C., fourth quarter 1998).
}

applications of the financially weakest prospective borrowers to several different lenders by sending out multiple applications on behalf of the applicants. ${ }^{18}$ To the extent that this practice creates relatively more multiple applications from less-creditworthy applicants compared with similar practices in other parts of the mortgage market, the denial rate for manufactured-home lenders would be higher than that of other mortgage lenders. Moreover, increased competition among lenders in the manufacturedhome loan market over the past few years may have encouraged dealers to shop applicants even more intensively among lenders and may help explain rising denial rates in this market.

\section{Subprime Mortgage Lending}

As in the manufactured-home mortgage market, almost all mortgages (94 percent) extended by lenders specializing in subprime loans and reporting under HMDA are conventional mortgages, with the bulk of the remainder insured by the FHA (table 2).

18. See Pramilia Gupta, Jeffery L. Woff, and Sombat Jiwariyavej, "Cracks in the Foundation: How Changing 'MH' Industry Dynamics Are Affecting Investors' Credit Risk," Moody's Structured Finance, October 2, 1998. 
6. Distribution of applications for conventional home-purchase loans and denial rate, by type of lender, 1993 and 1998 Percent

\begin{tabular}{|c|c|c|c|c|c|c|c|c|}
\hline \multirow{3}{*}{ Type of lender } & \multicolumn{4}{|c|}{1993} & \multicolumn{4}{|c|}{1998} \\
\hline & \multirow[b]{2}{*}{$\begin{array}{l}\text { Share of } \\
\text { applications } \\
\text { (1) }\end{array}$} & \multirow[b]{2}{*}{$\begin{array}{l}\text { Denial rate } \\
\text { (2) }\end{array}$} & \multicolumn{2}{|c|}{ Contribution to denial rate } & \multirow[b]{2}{*}{$\begin{array}{l}\text { Share of } \\
\text { applications } \\
\text { (1) }\end{array}$} & \multirow[b]{2}{*}{$\begin{array}{c}\text { Denial rate } \\
\text { (2) }\end{array}$} & \multicolumn{2}{|c|}{ Contribution to denial rate } \\
\hline & & & $\begin{array}{c}\text { Percentage } \\
\text { points } \\
(1) \times(2)\end{array}$ & Percent & & & $\begin{array}{c}\text { Percentage } \\
\text { points } \\
(1) \times(2)\end{array}$ & Percent \\
\hline Subprime ...... & .8 & 23.4 & .2 & 1.2 & 10.4 & 32.5 & 3.4 & 11.6 \\
\hline Manufactured-home . & 9.5 & 44.0 & 4.2 & 24.4 & 23.7 & 64.5 & 15.3 & 52.4 \\
\hline Prime & 89.6 & 14.3 & 12.8 & 74.4 & 65.9 & 16.2 & 10.7 & 36.0 \\
\hline All & 100 & 17.2 & 17.2 & 100 & 100 & 29.3 & 29.3 & 100 \\
\hline
\end{tabular}

In contrast, among prime lenders, governmentbacked loans (of all types) make up more than 20 percent of their home-purchase mortgages. HMDA data for earlier years show a similar pattern (not shown in table).

In 1998, subprime lenders received 10 percent of the 6.7 million applications for conventional homepurchase mortgages reported under HMDA and accounted for 6 percent of all the conventional homepurchase mortgages extended during that year.

\section{CREDIT STANDARDS, DENIALS, AND DELINQUENCIES IN THE SUBPRIME MARKET}

The credit risk of a loan is judged according to the features of the loan (such as term, interest rate, and size of the down payment), the financial characteristics of the borrower, and the value of the property that serves as collateral. Mortgages intended to be sold are graded from A (prime) to D as a means of summarizing the overall credit risk they pose. Two housing-related government-sponsored enterprises (GSEs) buy most of the prime mortgages that are offered for sale: the Federal National Mortgage Association (Fannie Mae) and the Federal Home Loan Mortgage Corporation (Freddie Mac). ${ }^{19}$

Subprime mortgages are those that in some way exceed the level of credit risk that the GSEs are willing to accept; subprime loans intended for sale receive a rating of $\mathrm{A}-, \mathrm{B}, \mathrm{C}$, or $\mathrm{D} .{ }^{20}$ Subprime loans that the lender chooses to retain have no need of a

19. Mortgages for amounts above a certain limit (adjusted annually) are by statute not eligible for purchase by the GSEs. These so-called jumbo mortgages nonetheless may be either prime or subprime in quality.

20. The GSEs may also purchase "alt-A" or "A-" mortgages that do not strictly meet their underwriting standards but that have some other characteristic that may make their credit risk equivalent to that of an A-rated mortgage. rating, and their quality could be better or worse than that of D loans.

The market for subprime home-purchase mortgages may be called a "residual" market. Although each subprime lender applies a standard for credit quality that will exclude some applicants, these lenders as a whole cannot easily be defined in terms of the maximum credit risk they will accept; nor can subprime borrowers be defined in terms of minimum credit quality. Thus, unlike the prime market, the subprime market has no clear "bottom" to the credit quality of applications that will be submitted nor of the loans that will be accepted.

Subprime lenders, who by definition accept higher risk, nonetheless have higher rates of denial than prime lenders, perhaps because many subprime lenders actively pursue mortgage applications from a group of potential borrowers who have a wider range of credit characteristics and circumstances than applicants in the prime market. Moreover, the underwriting standards used in the prime market may be more widely known than are the standards in the subprime market. This circumstance would allow applicants who do not meet the prime standards to more easily avoid a denial and apply instead in the subprime market.

Active solicitation of applicants by subprime lenders is applauded by some observers, who see it helping make mortgage credit and homeownership more widely available. Other observers disapprove of these solicitation practices, believing that they encourage some mortgage borrowers to apply for too much credit at too high an interest rate.

\section{How Subprime Loans Differ from Prime Loans}

Most subprime mortgages fail to meet prime standards in one of four ways. First, the borrower's credit history, typically summarized by a credit score based 
7. Denial rates on applications for conventional home-purchase loans for selected characteristics of applicant and census tract, by type of lender, 1993-98

Percent

\begin{tabular}{|c|c|c|c|c|c|c|c|c|c|c|c|c|}
\hline \multirow{2}{*}{ Characteristic } & \multicolumn{6}{|c|}{ Subprime } & \multicolumn{6}{|c|}{ Manufactured-home } \\
\hline & 1993 & 1994 & 1995 & 1996 & 1997 & 1998 & 1993 & 1994 & 1995 & 1996 & 1997 & 1998 \\
\hline $\begin{array}{l}\text { APPLICANT } \\
\text { Income ratio (percentage } \\
\text { of MSA median) }\end{array}$ & & & & & & & & & & & & \\
\hline $\begin{array}{l}\text { Lower } \ldots \ldots \ldots \ldots \ldots \\
\text { Middle } \ldots \ldots \ldots \ldots \ldots \ldots\end{array}$ & $\begin{array}{l}33.9 \\
20.1\end{array}$ & $\begin{array}{l}25.9 \\
19.1\end{array}$ & $\begin{array}{l}29.6 \\
22.2\end{array}$ & $\begin{array}{l}43.5 \\
27.8\end{array}$ & $\begin{array}{l}24.4 \\
19.6\end{array}$ & $\begin{array}{l}34.4 \\
24.9\end{array}$ & $\begin{array}{l}47.6 \\
38.8\end{array}$ & $\begin{array}{l}53.6 \\
42.4\end{array}$ & $\begin{array}{l}56.8 \\
48.1\end{array}$ & $\begin{array}{l}60.9 \\
51.3\end{array}$ & $\begin{array}{l}64.9 \\
54.8\end{array}$ & $\begin{array}{l}64.7 \\
55.7\end{array}$ \\
\hline Upper ................... & 18.0 & 16.1 & 19.1 & 19.4 & 16.6 & 19.1 & 32.1 & 32.1 & $\begin{array}{l}40.1 \\
39.3\end{array}$ & 42.1 & 44.8 & 47.2 \\
\hline $\begin{array}{l}\text { Racial or ethnic identity } \\
\text { American Indian or }\end{array}$ & & & & & & & & & & & & \\
\hline Alaskan Native & 25.6 & 19.1 & 28.1 & 57.5 & 28.4 & 46.7 & 48.4 & 56.1 & 61.6 & 66.1 & 67.5 & 70.5 \\
\hline Asian or Pacific Islander & 14.3 & 15.4 & 15.6 & 16.2 & 14.4 & 19.1 & 42.3 & 44.9 & 50.5 & 52.3 & 49.5 & 51.8 \\
\hline Black . & 26.7 & 25.6 & 29.0 & 48.9 & 21.9 & 39.2 & 58.4 & 58.8 & 64.2 & 70.7 & 74.4 & 76.1 \\
\hline Hispanic & 25.2 & 22.3 & 24.9 & 45.8 & 19.7 & 34.2 & 49.8 & 55.3 & 60.3 & 61.8 & 64.9 & 67.9 \\
\hline White . & 16.7 & 16.1 & 20.0 & 35.3 & 17.2 & 30.7 & 41.9 & 46.6 & 51.7 & 56.1 & 59.3 & 61.6 \\
\hline $\begin{array}{l}\text { Census TRACt } \\
\text { Income }\end{array}$ & & & & & & & & & & & & \\
\hline Lower & 34.2 & 27.3 & 28.8 & 39.9 & 23.1 & 28.9 & 47.5 & 51.1 & 55.5 & 59.2 & 63.5 & 63.0 \\
\hline Middle & 23.4 & 19.8 & 23.1 & 30.8 & 20.6 & 27.0 & 42.9 & 47.3 & 51.2 & 55.2 & 59.2 & 59.7 \\
\hline Upper . & 16.5 & 15.3 & 19.4 & 22.0 & 16.8 & 20.4 & 42.2 & 45.5 & 51.6 & 55.4 & 58.0 & 59.2 \\
\hline $\begin{array}{l}\text { Racial or ethnic } \\
\text { composition (minorities } \\
\text { as percentage of } \\
\text { population) }\end{array}$ & & & & & & & & & & & & \\
\hline Less than 10 . & $\begin{array}{l}25.9 \\
196\end{array}$ & 19.5 & 23.3 & 28.9 & $\begin{array}{l}19.9 \\
19 ?\end{array}$ & 24.7 & 42.1 & $\begin{array}{l}45.9 \\
48.9\end{array}$ & 50.1 & 54.3 & 57.4 & $\begin{array}{l}58.6 \\
60.9\end{array}$ \\
\hline $\begin{array}{l}10-49 \ldots \ldots \\
50-100 \ldots\end{array}$ & $\begin{array}{l}19.6 \\
29.8\end{array}$ & $\begin{array}{l}17.6 \\
25.6\end{array}$ & $\begin{array}{l}21.3 \\
27.3\end{array}$ & $\begin{array}{l}28.5 \\
37.1\end{array}$ & $\begin{array}{l}19.2 \\
22.7\end{array}$ & $\begin{array}{l}25.3 \\
28.2\end{array}$ & $\begin{array}{l}44.5 \\
48.6\end{array}$ & $\begin{array}{l}48.9 \\
51.1\end{array}$ & $\begin{array}{l}53.1 \\
56.9\end{array}$ & $\begin{array}{l}57.0 \\
59.9\end{array}$ & $\begin{array}{l}61.2 \\
64.2\end{array}$ & $\begin{array}{l}60.9 \\
65.0\end{array}$ \\
\hline All & 23.4 & 20.3 & 23.8 & 37.8 & 20.8 & 32.5 & 44.0 & 48.6 & 54.1 & 58.8 & 62.1 & 64.5 \\
\hline
\end{tabular}

on the borrower's previous payment experience, usually must meet a certain threshold for the borrower to be considered a prime-mortgage borrower. One common standard is the Fair Isaac Company's credit score, called the FICO score. ${ }^{21}$ Prime borrowers often have scores above 650 on an 800-point scale, whereas subprime borrowers often have scores from 550 to 650.

A second underwriting standard traditionally used in the prime market is that the monthly housing expenses of the borrower should not exceed 28 percent of pretax monthly income and that housing expenses plus other loan payments should not exceed 36 percent of pretax income. These ratios have become less strict in recent years, with lenders and the GSEs willing to accept higher ratios when there is evidence of other sources of financial strength. However, for ratios that are more than 5 percentage points above those mentioned here, the borrower would generally be considered subprime.

Third, whether they are prime or subprime, all mortgage borrowers are expected to earn an income sufficient for them to make their mortgage payment

21. For additional information about credit scoring, see Robert B. Avery, Raphael W. Bostic, Paul S. Calem, and Glenn B. Canner, "Credit Risk, Credit Scoring, and the Performance of Home Mortgages," Federal Reserve Bulletin, vol. 82 (July 1996), pp. 621-48. and other payment obligations. However, primemortgage borrowers are usually expected to document this ability with pay stubs, tax records, and other financial documents. One segment of the subprime mortgage market involves the extension of credit to borrowers who cannot, or do not want to, provide such documentation; this segment is referred to as the "low doc" or "no doc" mortgage market.

Finally, the terms of the loan can affect the credit risk to the lender. For A-rated borrowers, lenders typically lend no more than 80 percent of the home's value unless the homeowner also purchases private mortgage insurance to provide the lender additional protection in case the borrower defaults. Mortgages with loan-to-value ratios higher than 80 percent that do not have mortgage insurance or some other type of credit enhancement are often rated subprime.

Typically, lenders will have subprime mortgage programs that cater to borrowers that fail traditional underwriting criteria in only one of the ways mentioned above. For example, "low doc" loans do not require the same level of income documentation but often require that the homebuyer make a down payment that exceeds 20 percent of the loan value. Similarly, programs that target borrowers who desire high loan-to-value ratios often require such borrowers to have a pristine credit history as indicated by a relatively high FICO score. 


\section{7.-Continued}

\begin{tabular}{|c|c|c|c|c|c|c|c|c|c|c|c|c|}
\hline \multirow{2}{*}{ Characteristic } & \multicolumn{6}{|c|}{ Prime } & \multicolumn{6}{|c|}{ All } \\
\hline & 1993 & 1994 & 1995 & 1996 & 1997 & 1998 & 1993 & 1994 & 1995 & 1996 & 1997 & 1998 \\
\hline \multicolumn{13}{|l|}{$\begin{array}{l}\text { APPLICANT } \\
\text { Income ratio (percentage } \\
\text { of MSA median) }\end{array}$} \\
\hline Lower ................... & 18.1 & 16.3 & 18.4 & 20.8 & 21.5 & 17.6 & 21.5 & 22.7 & 29.9 & 34.2 & 37.0 & 35.6 \\
\hline Middle & 10.9 & 9.8 & 10.4 & 11.6 & 11.7 & 10.2 & 12.1 & 12.4 & 16.1 & 18.3 & 19.6 & 19.3 \\
\hline Upper ........... & 8.9 & 7.1 & 7.1 & 8.0 & 8.0 & 7.0 & 9.2 & 7.8 & 8.7 & 9.8 & 10.1 & 10.0 \\
\hline \multicolumn{13}{|l|}{ Racial or ethnic identity } \\
\hline Alaskan Native ... & 24.6 & 23.6 & 28.4 & 36.6 & 39.1 & 36.9 & 27.8 & 31.6 & 41.4 & 50.2 & 51.9 & 52.9 \\
\hline Asian or Pacific Islander & 14.3 & 11.3 & 10.9 & 12.3 & 11.5 & 9.6 & 14.6 & 12.0 & $\begin{array}{l}41.4 \\
12.5\end{array}$ & 13.8 & 12.7 & 11.8 \\
\hline Black ................. & 28.1 & 25.4 & 28.8 & 34.6 & 39.0 & 36.9 & 34.0 & 33.4 & 40.5 & 48.8 & 53.0 & 53.7 \\
\hline Hispanic & 22.9 & 19.9 & 21.3 & 24.5 & 27.3 & 24.4 & 25.1 & 24.6 & 29.5 & 34.4 & 37.8 & 38.7 \\
\hline White $\ldots \ldots \ldots \ldots \ldots \ldots$ & 12.5 & 11.8 & 13.4 & 15.3 & 16.2 & 14.0 & 15.3 & 16.4 & 20.6 & 24.1 & 25.8 & 26.0 \\
\hline \multicolumn{13}{|l|}{ Census Tract } \\
\hline Lower & 19.6 & 17.2 & 17.9 & 20.3 & 20.2 & 17.7 & 21.9 & 21.6 & 26.3 & 31.7 & 32.9 & 32.4 \\
\hline Middle & 12.4 & 10.8 & 11.4 & 13.3 & 13.5 & 11.6 & 14.3 & 14.5 & 18.0 & 21.4 & 23.4 & 23.0 \\
\hline Upper ... & 8.8 & 7.6 & 7.7 & 8.8 & 8.5 & 7.2 & 9.3 & 8.7 & 10.1 & 11.7 & 12.0 & 11.7 \\
\hline \multicolumn{13}{|l|}{$\begin{array}{l}\text { Racial or ethnic } \\
\text { composition (minorities } \\
\text { as percentage of } \\
\text { population) }\end{array}$} \\
\hline Less than 10 & 9.2 & 8.0 & 8.5 & 10.1 & 10.2 & 8.7 & 10.5 & 10.5 & 13.2 & 15.8 & 16.9 & 16.9 \\
\hline $10-49 \ldots \ldots$ & 13.3 & 11.5 & 12.0 & 13.5 & 13.3 & 11.3 & 14.8 & 14.7 & 18.2 & 21.6 & 22.9 & 22.2 \\
\hline $50-100$ & 21.6 & 18.6 & 18.8 & 21.3 & 20.7 & 18.3 & 23.0 & 21.8 & 25.6 & 30.7 & 31.4 & 31.0 \\
\hline All & 14.3 & 13.4 & 15.1 & 17.2 & 18.3 & 16.2 & 17.2 & 18.1 & 22.6 & 26.8 & 28.6 & 29.3 \\
\hline
\end{tabular}

Note. See notes to table 1 .

\section{Delinquencies and Regulatory Scrutiny in the Subprime Market}

About 63 percent of subprime loans are rated A-, 26 percent are rated $\mathrm{B}, 10$ percent are rated $\mathrm{C}$, and less than 2 percent are rated D. As expected, the proportion of loans that are delinquent rises as the credit quality of the loan falls. At the end of the first quarter of 1999, 3.1 percent of A- mortgages were seriously delinquent (more than ninety days past due or in foreclosure). ${ }^{22}$ In contrast, less than 1 percent of Fannie Mae's and Freddie Mac's mortgages were seriously delinquent. ${ }^{23}$

Regulators of depository institutions give activity in subprime mortgages special scrutiny, in part

22. In the other categories, 6.3 percent of B mortgages, 8.8 percent of $\mathrm{C}$ mortgages, and 21.5 percent of $\mathrm{D}$ mortgages were seriously delinquent ("B\&C Delinquencies Down in March 1999, MIC Data Reveal," Inside B\&C Lending, May 31, 1999).

23. These delinquency numbers may overstate the differences between subprime and prime mortgages, however, because delinquency statistics on subprime loans include not only home-purchase mortgages but also home equity loans (between 60 percent and 90 percent of subprime mortgage originations are first mortgages). See "Retail, A- Loans Pace the Subprime Market During 1999's First Quarter," Inside B\&C Lending, June 14, 1999. because of the high credit risks associated with such loans. Although such lending by depositories is usually only one part of a larger and more diverse mortgage portfolio, regulators require that institutions with significant proportions of subprime mortgages (or holding the credit risk associated with securities backed by such mortgages) hold relatively more capital against possible credit losses. ${ }^{24}$ Financial markets, too, require that lenders specializing in this part of the mortgage market carry more capital and operate under stricter financial requirements than lenders oriented toward prime borrowers.

Higher capital standards and potentially higher credit losses notwithstanding, many institutions have entered the subprime lending market in the past several years. Subprime lending was once the province of specialists who originated such mortgages to securitize and sell through public markets or to sell as "whole loans" to private investors. But now a significant number of depository institutions and large mort-

24. See Board of Governors of the Federal Reserve System, "Subprime Lending," Supervision and Regulation Letter 99-6, March 5, 1999. 
8. Share of applications for conventional home-purchase loans, grouped by selected characteristics of borrower and census tract and distributed by type of lender, 1993-98

Percent

\begin{tabular}{|c|c|c|c|c|c|c|c|c|c|c|c|c|}
\hline \multirow{2}{*}{ Characteristic } & \multicolumn{6}{|c|}{ Subprime } & \multicolumn{6}{|c|}{ Manufactured-home } \\
\hline & 1993 & 1994 & 1995 & 1996 & 1997 & 1998 & 1993 & 1994 & 1995 & 1996 & 1997 & 1998 \\
\hline \multicolumn{13}{|l|}{$\begin{array}{c}\text { APPLICANT } \\
\text { Income ratio (percentage } \\
\text { of MSA median) }\end{array}$} \\
\hline Lower & .9 & 1.5 & 1.8 & 2.9 & 4.4 & 10.8 & 11.1 & 16.7 & 29.3 & 31.8 & 35.5 & 34.4 \\
\hline Middle . & .9 & 1.4 & 1.9 & 2.5 & 4.6 & 10.3 & 4.0 & 7.5 & 14.5 & 15.8 & 17.4 & 16.7 \\
\hline Upper . . & .8 & 1.4 & 1.7 & 2.1 & 3.7 & 8.3 & 1.1 & 2.2 & 4.2 & 4.5 & 4.8 & 4.8 \\
\hline \multicolumn{13}{|l|}{$\begin{array}{l}\text { Racial or ethnic identity } \\
\text { American Indian or }\end{array}$} \\
\hline Alaskan Native & 6 & 9 & 1.1 & 2.7 & 2.3 & 10.4 & 13.5 & 24.7 & 39.2 & 44.0 & 46.0 & 44.6 \\
\hline Asian or Pacific Islander & 1.5 & 2.2 & 2.5 & 2.8 & 4.0 & 9.9 & .9 & 1.7 & 3.7 & 3.3 & 2.9 & 3.0 \\
\hline Black . & 1.4 & 1.9 & 2.4 & 4.5 & 5.8 & 16.5 & 19.5 & 24.0 & 33.1 & 37.4 & 42.4 & 42.0 \\
\hline Hispanic & 1.3 & 1.8 & 1.9 & 3.8 & 4.3 & 12.8 & 8.3 & 13.1 & 20.8 & 24.4 & 29.0 & 30.0 \\
\hline White . & .5 & .9 & 1.0 & 1.8 & 2.6 & 7.3 & 9.7 & 13.1 & 18.5 & 20.7 & 22.2 & 22.8 \\
\hline \multicolumn{13}{|l|}{$\begin{array}{l}\text { Census TRact } \\
\text { ancome }\end{array}$} \\
\hline Lower & 1.6 & 2.3 & 3.0 & 4.4 & 7.4 & 17.6 & 7.2 & 12.5 & 21.4 & 27.1 & 28.8 & 28.0 \\
\hline Middle . & .7 & 1.2 & 1.7 & 2.2 & 4.2 & 10.7 & 5.9 & 9.7 & 16.1 & 18.6 & 21.0 & 20.3 \\
\hline Upper . & .7 & 1.4 & 1.9 & 2.1 & 3.5 & 8.4 & 1.4 & 2.8 & 5.0 & 5.8 & 6.5 & 6.6 \\
\hline \multicolumn{13}{|l|}{$\begin{array}{l}\text { Racial or ethnic } \\
\text { composition (minorities } \\
\text { as percentage of } \\
\text { population) }\end{array}$} \\
\hline Less than $10 \ldots \ldots \ldots$ & .4 & .8 & 1.3 & 1.7 & 3.3 & $\begin{array}{r}8.0 \\
11.8\end{array}$ & 3.8 & 6.3 & 10.8 & 12.3 & 13.5 & 13.8 \\
\hline $\begin{array}{l}10-49 \ldots \\
50-100\end{array}$ & $\begin{array}{l}1.2 \\
2.1\end{array}$ & 1.9 & 2.4 & 2.9 & 4.7 & 11.8 & 4.7 & 8.3 & 14.5 & 17.4 & 19.5 & 18.5 \\
\hline $50-100$ & 2.1 & 2.9 & 4.0 & 5.5 & 9.1 & 22.4 & 4.5 & 9.4 & 17.0 & 22.0 & 24.1 & 22.5 \\
\hline All & .8 & 1.3 & 1.6 & 2.6 & 3.9 & 10.4 & 9.5 & 13.2 & 19.0 & 21.7 & 23.3 & 23.7 \\
\hline
\end{tabular}

gage bankers have subprime lending programs..$^{25}$ In addition, to the degree that the GSEs accept larger numbers of mortgages previously characterized as "subprime" under their underwriting standards (because, they would argue, new technologies and mortgage products allow them to better measure and accommodate credit risk), the volume of mortgages available to subprime originators diminishes.

\section{CHARACTERISTICS OF BORROWERS FOR SUBPRIME AND MANUFACTURED-HOME MORTGAGES}

The market for subprime mortgages differs from that for manufactured-home mortgages, but common to both is a relatively high proportion of lower-income and minority applicants and borrowers. In 1998, nearly 60 percent of the borrowers for manufactured-

25. With the expansion of these institutions into subprime lending, observers have raised concerns about "over competition" in the subprime market.

The subprime lending programs at most large depository institutions or their holding companies are usually kept separate from the bank's other mortgage lending activities because the business is quite different, with its emphasis on underwriting and servicing less creditworthy borrowers. home mortgages and nearly 30 percent of those for subprime mortgages were of lower income, whereas in the prime market the ratio was only 22 percent (table 3).

Among all subprime and manufactured-home lenders in 1998, the proportions of black and Hispanic borrowers ranged from a low of about 6 percent (Hispanic borrowers of manufactured-home mortgages) to about 14 percent (black borrowers of subprime loans); in the prime market that year, about 4 percent of the borrowers were black and about 5 percent were Hispanic. Subprime and manufactured-home lending is also relatively more concentrated in lower-income and minority neighborhoods.

Regarding their share of all lower-income and minority borrowers, subprime and manufacturedhome lenders together in 1998 provided one-fifth of the mortgages extended by all lenders to lowerincome borrowers, one-third of the mortgages extended to black borrowers, and one-fifth of the mortgages extended to Hispanic borrowers (memo items, table 3). In contrast, only 7 percent of upperincome borrowers took a mortgage from a subprime or manufactured-home lender, and only about 12 percent of white borrowers obtained mortgages from these sources. 
8.-Continued

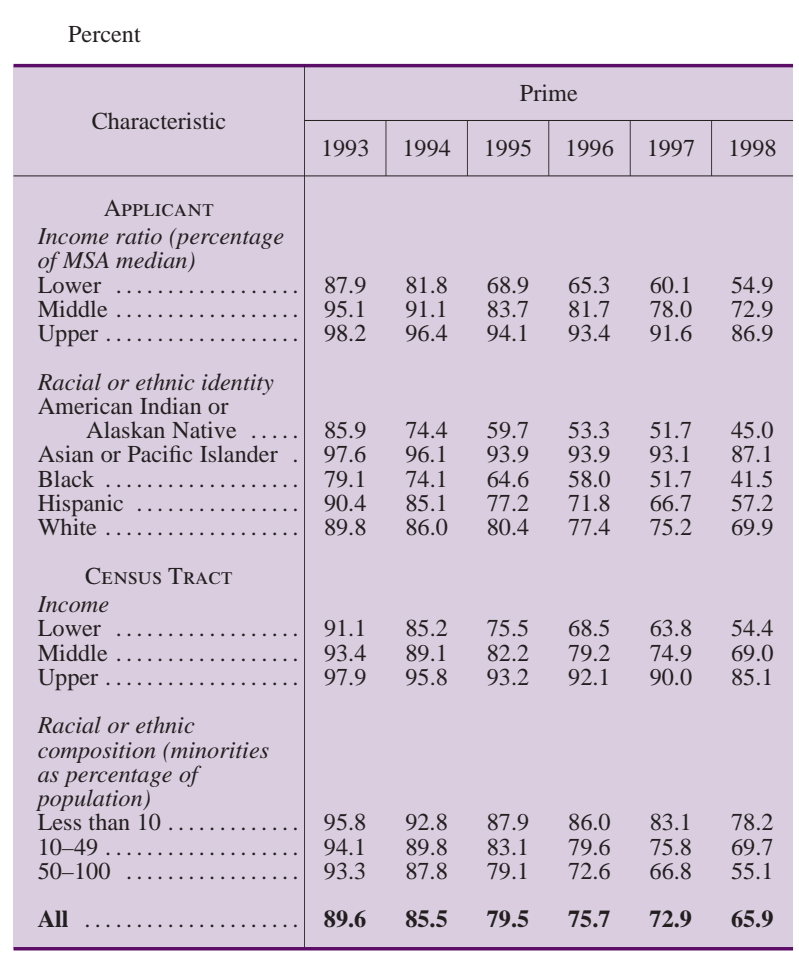

NoTE. Sum of percentages across lender types for a given characteristic in a given year equals 100 . See also notes to table 1 .

\section{CHANGES IN CONVENTIONAL HOME-PURCHASE LENDING}

As noted above, since 1993 the number of conventional home-purchase mortgages has increased nearly 51 percent, with relatively larger increases among lower-income and minority homebuyers and neighborhoods (table 1). Favorable economic conditions, expanded mortgage market competition, new information technology, relatively rapid minority population growth, and recently developed affordable homeloan programs have all contributed to this high growth rate. All borrowers in the mortgage market have benefited from these trends, but perhaps lowerincome borrowers, including those that rely on subprime and manufactured-home loans, have benefited the most because their creditworthiness is more likely to improve-and more likely to be discovered by lenders - under these circumstances.

Although small in number, subprime and manufactured-home lenders accounted for about onethird of the growth in mortgage lending from 1993 to 1998 (table 4). Their shares of the growth among lower-income and minority borrowers and neighborhoods was even larger, ranging from 40 percent to nearly 60 percent. In contrast, their shares of the increase in lending to upper-income and white borrowers were significantly lower- 18 percent and 31 percent respectively. As a result, subprime and manufactured-home lenders' share of conventional home-purchase mortgages extended to lower-income and minority borrowers tripled (quadrupled in the case of Hispanic borrowers) over the period, reaching levels of one-fifth to one-third (table 5).

Although prime market lenders accounted for the remainder of the growth in lending, some of their expansion also likely consists of an increase in subprime and manufactured-home lending, in part because of recent acquisitions of some of these specialized lenders. Many of the prime lenders have been aggressively pursuing lower-income homebuyers, partly in an effort to develop new profitable market niches and to respond to public concerns about the availability of such lending; prime lenders may see subprime and manufactured-home lending as one way to reach more of these borrowers. ${ }^{26}$ As a consequence, our measure of the proportion of growth in mortgage lending attributable to subprime and manufactured-home lending may be understated because we count such mortgages only when they are made by institutions that specialize in these areas.

\section{THE INFLUENCE OF SUBPRIME AND MANUFACTURED-HOME LENDERS ON MORTGAGE DENIALS}

Denial rates for conventional home-purchase mortgages have been increasing steadily, rising from 17 percent in 1993 to 29 percent in 1998 (table 6). Some observers are concerned that this trend might indicate that mortgage lenders are exerting less effort in providing home-purchase credit to all segments of their communities, including lower-income and minority applicants. Others believe quite the opposite- that increased efforts by traditional mortgage lenders to reach borrowers whose creditworthiness is weaker or more difficult to determine have resulted in both more mortgage lending and more denials.

Both these views ignore the increasing share of conventional home-purchase mortgage applications going to subprime and manufactured-home lenders that, by the nature of their business, have high and, as

26. See Glenn Canner and Wayne Passmore, The Community Reinvestment Act and the Profitability of Mortgage-Oriented Banks, Finance and Economics Discussion Series 1997-7 (Board of Governors of the Federal Reserve System, July 1997). 
9. Share of denials on applications for conventional home-purchase loans, grouped by selected characteristics of borrower and census tract and distributed by type of lender, 1993-98

Percent

\begin{tabular}{|c|c|c|c|c|c|c|c|c|c|c|c|c|}
\hline \multirow{2}{*}{ Characteristic } & \multicolumn{6}{|c|}{ Subprime } & \multicolumn{6}{|c|}{ Manufactured-home } \\
\hline & 1993 & 1994 & 1995 & 1996 & 1997 & 1998 & 1993 & 1994 & 1995 & 1996 & 1997 & 1998 \\
\hline \multicolumn{13}{|l|}{$\begin{array}{l}\text { APPLICANT } \\
\text { Income ratio (percentage } \\
\text { of } M S A \text { median) }\end{array}$} \\
\hline Lower & 1.5 & 1.7 & 1.8 & 3.7 & 2.9 & 10.4 & 24.6 & 39.5 & 55.8 & 56.7 & 62.3 & 62.4 \\
\hline Middle & 1.5 & 2.2 & 2.6 & 3.8 & 4.6 & 13.3 & 12.8 & 25.5 & 43.2 & 44.3 & 48.7 & 48.3 \\
\hline Upper . . & 1.5 & 2.9 & 3.7 & 4.1 & 6.0 & 15.9 & 3.7 & 9.2 & 19.2 & 19.4 & 21.3 & 22.7 \\
\hline \multicolumn{13}{|l|}{$\begin{array}{l}\text { Racial or ethnic identity } \\
\text { American Indian or }\end{array}$} \\
\hline Alaskan Native & .5 & .5 & .7 & 3.1 & 1.2 & 9.2 & 23.5 & 43.9 & 58.3 & 58.0 & 59.8 & 59.4 \\
\hline Asian or Pacific Islander & 1.5 & 2.8 & 3.1 & 3.3 & 4.6 & 15.9 & 2.6 & 6.4 & 14.8 & 12.5 & 11.3 & 13.2 \\
\hline Black ................ & 1.1 & 1.4 & 1.7 & 4.6 & 2.4 & 12.1 & 33.4 & 42.2 & 52.4 & 54.3 & 59.6 & 59.4 \\
\hline Hispanic & 1.3 & 1.6 & 1.6 & 5.0 & 2.2 & 11.3 & 16.4 & 29.5 & 42.6 & 43.9 & 49.7 & 52.6 \\
\hline White . & .6 & .9 & 1.0 & 2.7 & 1.7 & 8.6 & 26.4 & 37.3 & 46.5 & 48.3 & 51.0 & 53.9 \\
\hline \multicolumn{13}{|l|}{ Census Tract } \\
\hline Lower & 2.5 & 2.8 & 3.3 & 5.5 & 5.2 & 15.7 & 15.7 & 29.5 & 45.2 & 50.7 & 55.7 & 54.5 \\
\hline Middle & 1.2 & 1.7 & 2.1 & 3.2 & 3.7 & 12.6 & 17.8 & 31.6 & 45.8 & 47.8 & 53.1 & 52.7 \\
\hline Upper .... & 1.3 & 2.4 & 3.6 & 4.0 & 5.0 & 14.5 & 6.1 & 14.7 & 25.5 & 27.3 & 31.4 & 33.0 \\
\hline \multicolumn{13}{|l|}{$\begin{array}{l}\text { Racial or ethnic } \\
\text { composition (minorities } \\
\text { as percentage of } \\
\text { population) }\end{array}$} \\
\hline Less than $10 \ldots \ldots \ldots$. & 1.0 & 1.6 & 2.2 & 3.0 & 3.9 & 11.7 & 15.2 & 27.7 & 41.0 & 42.3 & 46.0 & 47.9 \\
\hline $10-49 \ldots \ldots$ & 1.6 & 2.3 & 2.7 & 3.9 & 3.9 & 13.5 & 14.2 & 27.6 & 42.4 & 46.1 & 52.1 & 50.8 \\
\hline $50-100$ & 2.8 & 3.4 & 4.3 & 6.6 & 6.6 & 20.3 & 9.6 & 21.9 & 37.7 & 42.9 & 49.4 & 47.2 \\
\hline All & 1.1 & 1.4 & 1.6 & 3.6 & 2.8 & 11.6 & 24.4 & 35.3 & 45.3 & 47.6 & 50.5 & 52.1 \\
\hline
\end{tabular}

indicated by recent trends, increasing denial rates (table 7). In fact, our analysis of HMDA data indicates that the denial rate among prime lenders has increased relatively little since 1993, and even this small increase may be due primarily to their increased participation in the subprime and manufactured-home markets.

The changing influence of different types of lenders in determining mortgage denial rates is illustrated by decomposing the overall denial rate into the shares attributable to each type of lender. In 1993, prime lenders were responsible for about three-fourths of the overall denial rate (table 6). By 1998, however, the situation was nearly reversed, with prime lenders accounting for only 36 percent of the overall denial rate and subprime and manufactured-home lenderswith the latter being by far more important in this regard-accounting for 63 percent. At present, the activity of these specialized lenders is largely determining the current level and change in denial rates.

\section{Manufactured-Home Lenders}

Lenders specializing in manufactured-home mortgages are denying applications at a high and rising rate. In 1993, these lenders denied about 44 percent of the applications for conventional home-purchase mortgages they received, compared with an average of 17 percent for all lenders reporting under HMDA (table 7). By 1998, their denial rate had increased to nearly 65 percent, compared with an overall denial rate of 29 percent.

The increase in the denial rate by manufacturedhome lenders has strongly influenced the overall trend in denial rates observed in the HMDA data because these lenders have received an increasing share of all applications. From 1993 to 1998 their share of all conventional home-purchase mortgage applications reported in the HMDA data rose about $2 \frac{1}{2}$ times, to about 25 percent, and their share of all reported denials of such applications approximately doubled, to about 50 percent (tables 8 and 9).

The trends hold true across all household and neighborhood groups, with the exception of Asian applicants, and can be attributed in large measure to the increased shares of applications accounted for by manufactured-home lenders and their high and rising denial rates. For example, between 1993 and 1998, the denial rate for black applicants rose from 34 percent to 54 percent overall and from 58 percent to 76 percent at manufactured-home lenders (table 7). For white applicants, the rate of denial moved by comparable proportions over the same period.

Like the pattern nationally, part of the rise in denial rates across all household and neighborhood groups 
9.-Continued

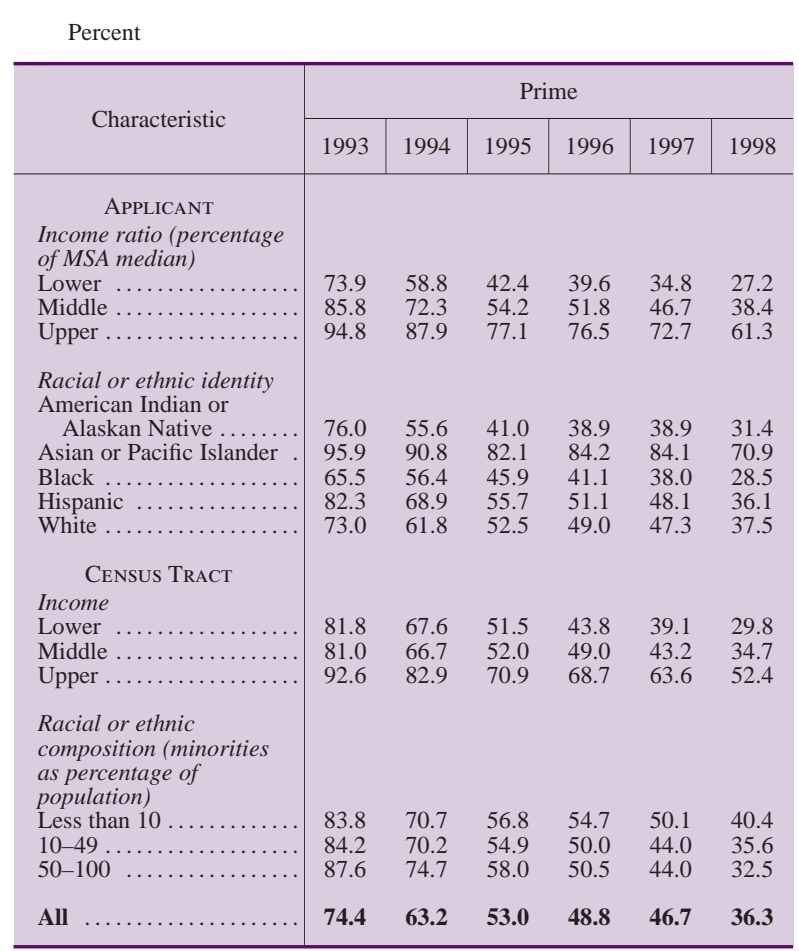

NotE. Sum of percentages across lender types for a given characteristic in a given year equals 100 . See also notes to table 1 .

is accounted for by the increasing share of applications for conventional home-purchase mortgages made to manufactured-home lenders. In particular, manufactured-home mortgages are of growing importance to black, Hispanic, and American Indian mortgage applicants (table 8). For example, in 1993, 20 percent of all applications for home-purchase mortgages from black applicants were made to manufactured-home lenders; by 1998, the proportion was 42 percent. For Hispanic applicants, the proportion changed even more sharply, rising from 8 percent to 30 percent of all applications during the period.

Manufactured-home loans are also of growing importance to lower-income applicants, with 34 percent applying to manufactured-home mortgage specialists in 1998, up from 11 percent in 1993. Upperincome households do not frequently apply for loans from these lenders, although the percentage for this group also increased, from 1 percent to 5 percent, over the period (table 8).

With a rising share of the applications and a characteristically high denial rate, manufactured-home lenders are of increasing importance in the denial of mortgage credit, and the trend is reflected across all ethnic, racial, and income groups (table 9). In 1993, manufactured-home lenders accounted for one-third of all denials for black applicants; by 1998, they accounted for three-fifths. The change is more striking for lower-income applicants; the proportion of denials accounted for by these lenders rose from one-fourth to more than three-fifths.

\section{Subprime Mortgage Lenders}

Lenders specializing in subprime mortgages also have high and rising denial rates (although only about half those of manufactured-home lenders). In addition, the share of all mortgage applications submitted to subprime lenders has increased. Thus, the increase in denial rates by subprime lenders has had some influence on the overall trend in denial rates observed in the HMDA data, although the influence is much less than that of the manufactured-home lenders.

Some of the patterns seen in the data for manufactured-home lenders relative to prime lenders-an increasing share of all applications for conventional home-purchase loans as well as an increasing share of all denials-is evident for subprime lenders. Their share of applications in the HMDA data has only recently become important, moving from 1 percent in 1993 to 10 percent in 1998; likewise their share of denials in the HMDA data moved from 1 percent to 12 percent over the period (table 6). The rate at which subprime lenders denied applications also climbed markedly in the 1993-98 period, from 23 percent to 33 percent, while the rate for prime lenders rose at a comparatively mild pace, from 14 percent to 16 percent (table 7). In terms of racial and ethnic groups, the denial rate for whites at manufactured-home and subprime lenders alike rose sharply, whereas it moved only slightly at prime lenders (table 7).

One notable difference between manufacturedhome lenders and subprime lenders is in the denial rate for black applicants. The rate throughout the 1993-98 period was much higher for manufacturedhome lenders than it was for prime lenders; in contrast, the rates for subprime and prime lenders each began the period at about the same level, rose about 10 percentage points, and ended at somewhat under 40 percent (table 7).

Another difference is that, unlike manufacturedhome lenders, subprime lenders accounted for roughly equal (albeit rising) shares of applications from each broad income group over the period. Thus, in 1998, the subprime specialists' share of all lowerincome applicants was fractionally larger than their share of upper-income applicants (11 percent versus 
8 percent), whereas the manufactured-home lenders' share of lower-income applicants was about seven times larger than their share of upper-income applicants (table 8).

The importance of subprime lenders on overall denials is reflected across all ethnic, racial, and income groups (table 9). For example, subprime mortgage lenders accounted for 1 percent of all denials of black applicants in 1993; by 1998, these lenders accounted for 12 percent.

\section{CONCLUSION}

We investigated the influence of lenders that specialize in subprime and manufactured-home lending on the growth of conventional home-purchase mortgage lending and on one closely followed measure of access to credit-denial rates for conventional homepurchase loans. The data show that these lenders, although small in number, contributed significantly to the recent growth in conventional home-purchase lending to lower-income and minority households and neighborhoods and that they accounted for much of the change in denial rates over the period from 1993 to 1998. In particular, the business of lending to finance manufactured homes, with its orientation toward lower-income and relatively less creditworthy borrowers, plays a key role in understanding both the increased availability of credit to lower-income borrowers and the recent rise in denial rates for conventional home-purchase loans.

\section{APPENDIX A: PROVISIONS OF HMDA}

Since the Home Mortgage Disclosure Act of 1975, depository institutions-commercial banks, savings associations, and credit unions-with offices in metropolitan statistical areas (MSAs), along with their mortgage lending subsidiaries, have been required to disclose to the public information about the geographic location of the home-purchase and homeimprovement loans they originate or buy.

Over time, amendments have added other types of institution to the act's coverage. First, amendments passed in 1988 extended coverage to savings and loan service corporations and to the mortgage banking subsidiaries of depository institution holding companies. Amendments passed in 1989 extended coverage to independent mortgage companies-for the first time capturing lenders unaffiliated with depository institutions.
Expansion in the geographic boundaries and numbers of MSAs, together with the growth in assets at institutions previously exempt from coverage, also increased the number of institutions covered by HMDA. But in recent years an important influence on the number of institutions covered has been the merging of organizations and the increase in the asset exemption for reporters. ${ }^{27}$ For 1998 , about 7,800 institutions reported on their lending activity, a decrease from the peak of 9,900 in 1994. ${ }^{28}$

The 1989 amendments to HMDA also greatly increased the information reported under the act. Instead of focusing solely on credit extensions, the reporting was expanded to include applications and their disposition-that is, whether they were approved, denied, withdrawn, or had their files closed for incompleteness. Reporting institutions also must now disclose information about the race or national origin, sex, and annual income of loan applicants and borrowers. Further, for loans originated or purchased during the year, institutions must report the loans they sold, classified by type of purchaser. Finally, they may, if they wish, report their reasons for denying loans. For 1998, about 25 million loans and applications were covered by the act and reported by institutions.

\section{APPENDIX B: IDENTIFYING SUBPRIME AND MANUFACTURED-HOME LENDERS}

The HMDA data do not provide a direct method of identifying institutions that specialize in subprime or manufactured-home lending. Consequently, staff members of the U.S. Department of Housing and Urban Development (HUD) each year use the data, along with several indirect methods, to compile a list of these lenders, primarily for regulatory purposes. ${ }^{29}$

First, and most important, a list of manufacturedhome and subprime lenders is created from various trade publications and industry sources. A second list is created by scanning the HMDA data for lenders with high denial rates or with 90 percent or more of their activity in refinancings. Finally, a list of lenders

27. Until 1996, depository institutions with assets of $\$ 10$ million or less were exempt. For 1997, in response to amendments to HMDA, the threshold was raised to $\$ 28$ million to account for the effects of inflation from 1976 to 1996 . The minimum asset threshold was increased to \$29 million in 1998 and remained at this level for 1999 .

28. For more detail, see the July 29, 1999, press release of the Federal Financial Institutions Examination Council.

29. The names and identification numbers of the home lenders compiled by HUD each year is in Randall M. Scheessele, 1998 HMDA Highlights, Housing Finance Working Papers (Department of Housing and Urban Development, October 1999). 
B.1. Number of lenders and number of conventional home-purchase loans, grouped by year and distributed by type of lender, 1993-98

\begin{tabular}{|c|c|c|c|c|c|c|c|c|}
\hline \multirow{2}{*}{ Year } & \multicolumn{2}{|c|}{ Subprime } & \multicolumn{2}{|c|}{ Manufactured-home } & \multicolumn{2}{|c|}{ Prime } & \multicolumn{2}{|c|}{ All } \\
\hline & Institutions & Loans & Institutions & Loans & Institutions & Loans & Institutions & Loans \\
\hline 1993 & 21 & 15,594 & 6 & 103,752 & 9,627 & $2,251,842$ & 9,654 & $2,371,188$ \\
\hline 1994 & 31 & 30,551 & 7 & 151,543 & 9,822 & $2,613,068$ & 9,860 & $2,795,162$ \\
\hline 1995 & 39 & 31,677 & 7 & 204,430 & 9,503 & $2,500,021$ & 9,549 & $2,736,128$ \\
\hline 1996 & 58 & 39,206 & 10 & 228,461 & 9,260 & $2,658,430$ & 9,328 & $2,926,097$ \\
\hline $1997^{\circ}$ & 122 & 78,737 & 10 & 243,463 & 7,795 & $2,715,166$ & 7,927 & $3,037,366$ \\
\hline $1998^{1}$ & 239 & 220,511 & 22 & 283,000 & 7,576 & $3,073,221$ & 7,837 & $3,576,732$ \\
\hline
\end{tabular}

1. Many small institutions became exempt from HMDA reporting requirements because of an increase in the asset threshold for coverage under the law.

with certain words in their names, for example, "consumer," "discount," "finance," and "equity" are culled from the list of institutions covered by HMDA. The three lists are then merged. Institutions are dropped from this consolidated list if they also appear on lists of lenders that specialize in FHA lending or of lenders that sell a large share of their loan originations to Fannie Mae or Freddie Mac-activities not characteristic of specialists in subprime and manufactured-home lending.

At this point, lenders on the consolidated list are called and asked whether their organizations engage in subprime and manufactured-home lending and whether they specialize in these businesses. If they say they are specialists, they are counted as such. If they respond that they do not engage in the business, they are counted as prime lenders. If they say they participate but do not specialize, they are asked to estimate the percentage of their loans that are subprime or are for manufactured homes; if the percentage is more than 50 percent, they are classified as specializing in that area.

Once an institution is classified as being either a prime, subprime, or manufactured-home lender, all of the applications and loans reported by that lender in the HMDA data are counted in our analysis as being of the institution's type. But many institutions in each type make loans characteristic of the other two types. For example, banking organizations have recently expanded their operations by purchasing some subprime and manufactured-home lenders. If the operations of the merged firms are then combined, the subprime and manufactured-home lending of these organizations will no longer be distinguishable from their other home lending.

Including entry and exit of firms during the 1993-98 period, about 350 institutions that report under HMDA have been identified in one or more years as subprime or manufactured-home lenders (table B.1). The number identified each year has grown, however, in part because of expanded opportunities in the relatively fluid subprime market, where institutions tend to enter or exit the business as market conditions change. The number of manufacturedhome loan specialists, in contrast, is relatively small, and the industry is highly concentrated. 